\title{
Cultural Meaning of The Morge Siwe Wedding of Kayu Agung People, South Sumatera
}

\author{
Ery Agus Kurnianto ${ }^{1}$, Mochammad Fikri ${ }^{2}$ \\ \{eratomainaka@gmail.com\} \\ Jalan Elang Raya 1, Magunharjo, Tembalang, Semarang
}

\begin{abstract}
This study will reveal the symbolic meaning of Morga Siwe wedding, Kayu Agung, South Sumatra. This study is very interesting to do because the traditional ritual has many stages. Every stage that appears is laden with noble values of Kayu Agung people. In addition, this study is interesting because the researcher has not found any writings discussing about Morga Siwe wedding. The purpose of this study is to find and describe the noble values represented in every stage of Morga Siwe marriage. This study is an explanation that discusses Morga Siwe wedding ceremony, both the meaning of words, language, and the meaning of symbols, and thus comes to an interpretation of the meaning in the proceedings. The results of the interpretation are related to the lifestyle, habits, and culture of Kayu Agung people so that it gives an educational effect, especially moral education based on the noble values of Kayu Agung people. The method used in this study is the mythological theory of Roland Barthes. Data about Morga Siwe is obtained by using literature and observation methods.
\end{abstract}

Keywords: The Symbolic Meaning, Wedding Ceremony, Morga Siwe

\section{Introduction}

Oral tradition is one of enrichment elements of Indonesian culture. This national enriching element is a cultural reflection of the existence of a social community which is full of noble values and is used as a philosophy of life. These values are based on the concept of local genious. Haryati Soebandio in Nurmalinda [1] states that local genious is also called culture identity, which means the ability of a social community in the form of a cultural identity that impacts the social community of having the competence to adopt a foreign culture that is adjusted to its own character and abilities.

Therefore, oral traditions need to be maintained, built, studied, and developed based on origin culture that have been formed as an effort to maintain their existence and survival in society. This step needs to be taken so that an understanding emerges in the community that oral literature does not only contain things that are fictional in nature. Sibrani [2] states that oral traditions are not only limited to things that are said which are different from what is written. Oral tradition is a form of oral tradition that is patterned, exist in society as a shared knowledge, and its inheritance is carried out through speech so that various versions will emerge. Supriatin [3] states that oral tradition is a legacy of ancestors full of local culture, policies, and life philosophies which are represented through spell, proverbs, performances, and traditional ceremonies that exist in society. 
Edi Sedyawati [4] further states that oral tradition contains social and cultural aspects. It contains of the subject of the oral tradition, the objectives of the oral tradition, and the method or system of carrying out the oral tradition. Cultural aspects include values represented through oral traditions, rules of traditions, and the use of symbols in oral traditions. Value is something that is very useful for human life [5]. Danandjaja [7] states that there are several things that can be used to identify the oral tradition. These are (a) oral methods are used to bequeath and disseminate; (b) has a character according to tradition; (c) has different forms and variants; (d) anonymous; (e) has a pattern; (f) the collective community has benefits or functions; ( $g$ ) has its own logic; (h) becomes collective property; (i) innocence.

It cannot be denied that in this modern and digital era, oral traditions are getting less attention. This is due to a shift in lifestyle, a shift towards a pragmatic culture that forgets the process and the consumption of public entertainment. Morge Siwe is one of the oral traditions owned by Kayu Agung people. This oral literature takes the form of a traditional wedding ceremony. The traditional wedding ceremony has very long and long stages. For reasons of effectiveness and efficiency, not all stages of the traditional wedding ceremony are carried out by its people.

Eliminating several stages in Morge Siwe traditional on the grounds of efficiency and effectiveness results in the loss of a noble heritage values that are contained in this traditional. The neglect or even the elimination of an oral tradition will have an impact or influence on the cultural identity of its people. Based on that such thing, the problem to be investigated is what is the cultural meaning of Morge Siwe marriage of Kayu Agung people, South Sumatra? The purpose of this research is to reveal and describe the cultural meaning of Morge Siwe marriage of Kayu Agung people, South Sumatra. This is due to local wisdom inherent in local culture. Therefore, in order to understand the local wisdom of a social community, the culture of the social community also needs to be studied [7].

Marriage is one form of application of a culture in human life. Through marriage, humans will build an atmosphere and sense of mutual love, love among family members. As stated in UU Number 1 at 1974 [8], Article 1 states that:

"Marriage is a physical and mental bond between a man and a woman as husband and wife with the aim of forming a Happy and eternal family (household) based on the God."

Marriage is one of the sacred traditional which is carried out based on the ancestral marriage tradition. For this such thing, Kayu Agung people use Morge Siwe marriage.

Myth is a work contains aesthetic values. Each myth has a different style and way of expressing beauty. Myth contains of elements of history and a cultural institution. For people who own it, myth has a very significant role and function in social life [9]. Related to this, Suyitno [10] says that the values of people's lives have a very significant influence on oral traditions as a result of cultural products. Therefore, it is not surprising that the values contained in the oral tradition represent the noble values of its people. In a certain time, the values contained in an oral tradition will have a function or benefit for its people. Yohana [11] states that oral tradition as an expression of regional culture has a function as a means of social interaction for its people. Oral traditions are used to convey the meaning by using the media of traditional languages and customary laws that are followed and apply in society.

The oral tradition is full of myths that embody noble values. Therefore, myth has an important role in individual and social life to carry out agreed-upon social institutions or can be called as social control in people's lives. Eller [12] states that myth is nothing more than a model or living guide. Barthes states that there are three things that cannot be separated from a myth, namely the signifier, the signife, and the sign. The tagging system consists of an expression (E), 
and a content domain $(\mathrm{C})$. The marking $(\mathrm{R})$ arises from the relationship between $\mathrm{E}$ and $\mathrm{C}$. The combination of the three E, C, and R will produce a second layer of meaning [13].

\section{Research Methods}

Descriptive method is applied in this research using a pragmatic approach. The pragmatic approach is used to reveal the usefulness of a work for the audience, which refers to the social reality that exists around the people. This approach is based on the reader. Readers are the target to convey norms and moral values. The data of this research is Morge Siwe wedding ceremony. The data is obtained in two ways. First, the researchers met directly with the informants.

From this informant, the researcher obtained information about Morge Siwe wedding ceremony and the social background of Kayu Agung people. The technique used to extract this information is record notes. Second, researchers conducted a literature study. Researchers read both books and journal articles, that are related to this research problem.

\section{Results and Discussion}

\section{Overview Of Margo Siwe Cultural Ceremony}

Morge Siwe is one of the traditional wedding ceremonies in South Sumatra, precisely Kayu Agung. This tradition is a series of traditional events passed down by ancestors to the younger generation. The purpose of carrying out this traditional wedding ceremony is so that the household becomes full of happiness, prosperity, and brings favors and gifts in the future. Households that are built will avoid negative things which can eventually lead to divorce.

Morge Siwe is carried out by Kayu Agung people, which is the original ethnic group of Ogan Komering Ilir. In addition to Kayu Agung ethnic group, the original ethnic groups of Ogan Komering Ilir are Pegagan, Komering, and Penesak ethnic groups. Pegagan ethnic groups can be found around the lower reaches of Komering River, namely in Serinanti, Sugiwaras, and surrounding areas. Komering ethnic group can be found around the headwaters of Komering River which includes Tanjung Lubuk area, Pedamaran part of Kayu Agung (the Lempuing area and its surroundings). Penasak people lives around in Pedamaran District area (apart from Sukaraja Village).

Based on the information from an informant (Rahman, 75 years old), Morge Siwe wedding ceremony has four levels. Each level is carried out in accordance with the strength of the financial condition and situation. The four levels of the traditional wedding ceremony are.

1. Setinong-tinong wedding ceremony

Setinong-tinong wedding ceremony usually carried out by people with weak economy condition. This traditional wedding ceremony is very simple and leaves behind a series of traditional wedding rituals that require a very high cost. Setinong-tinong wedding ceremony usually straight to the main event of the traditional wedding ceremony, which is Ijab Kabul, a sign that a husband and wife are legal to build a household. This ceremony is so simple that there is a term "kawin biyas secumpuk tahlui osai" which means a wedding ceremony that is carried out in a very simple way.

2. Sepinong-pinong wedding ceremony

No different from the Setinong-Tinong wedding ceremony, Sepinong-pinong traditional ritual is also more concerned with the legitimacy of a wedding procession 
which is marked by the ongoing of Ijab Kabul. The thing that distinguishes sepinongpinong is that there is Utoran. Utoran is an event of serving food for invited guests. This kind of wedding ceremony is also carried out by people with weak economy condition.

3. Pinang dibelah wedding ceremony

This wedding ceremony is usually carried out by the "kawin lari" couple or known as setakatan. This wedding ceremony is carried out by middle class people. The wedding ceremony is carried out in a simple manner, but not as simple as setinong-tining and sepinong pinong.

4. Mabang handak wdding ceremony

Mabang handak wedding ceremony is the most complex wedding ceremony of them all. This kind of wedding ceremony ussualy cerried out by upper class people. This is because the stages carried out in the event require a very large cost. There are three stages in this Wedding ceremony.

a. Pre-wedding

The steps that must be done at the pre-wedding are maju and bengiyan ngulom bobon Morge Siwe, kilu woli nikah, ningkuk, set up wards, ngebengiyankon, nguak and ngulom, patisapi, ngantat pekurangan, midang, and mullah.

b. Wedding

The steps that must be done at wedding are Turgi or Nugi (nyungsung maju, receiving pesalin clothes, mapak ungaian, akad nikah, juluk, manjaw kahwin, cang-cang dance, ngantoto san-san, kereta juli, dan kecuwakan mongan), ngarak pacar, anan luwoi.

c. Post-wedding

the events in it are lang ulangan, nganan tuwoikon maju, nglangkon pukal, and anan tuwoi semehongot.

\section{Cultural Meanings of Morge Siwe Wedding Ceremony}

In each stage of the culture Morge Siwe wedding ceremony, pre-wedding, wedding, and post-wedding, it is full of noble values. These values represent the cultural level owned by Kayu Agung people that highly upholds social values; trust, respect, unity and integrity, and help each other. Giving help to those who capable and asking for help for those in need shows how strong the social life in Kayu Agung people. This results a very few social conflicts in Kayu Agung people live.

\section{Cultural Meaning of Morge Siwe Pre-wedding Ceremony}

The harmony of the social life of the Kayu Agung people is represented in Morge Siwe prewedding ceremony at the stage of establishing a tarub or ward and ngebengiyankon, and Mulah. The three stages of the pre-wedding ceremony show how harmonious of Kayu Agung people's social life which one of their characteristics. Tarubs or wards for wedding are established together between family who owns the celebration and people around it. Likewise, at ngebengiyankon stage.

In Indonesian, ngebengiyankon means asking for help. In this stage, the host family who carries out the celebration will visit the family, relatives, and the neighbors to ask for help in carrying out the wedding ceremony. During the visit, the host family usually brings a gift as a thank you for the help. During the visit, usually people who are asked for help will not even refuse requests from the host family. The stages of Mulan are held together with neighbors and family. Mulan is a traditional event involving cooking goat, cow, or buffalo curry which is done 
on Saturdays. They will cook curry together. From the process of slaughtering a cow or buffalo, preparing seasonings, until cooking all done together. It will be served at the wedding ceremony and enjoyed together.

Respecting each other is represented in the traditional events Maju and Bengiyaan Ngulom Bobon Margo Siwe. Respect for family and people by coming and inviting them one by one to the wedding. At the stage of the traditional event, Maju and Bengiyaan Ngulom Bobon Margo Siwe, the host family will come to relatives and neighbours to invite them to the wedding that will be held. This represents the very high respect that exists in the life of Kayu Agung people. Visiting, giving news, and inviting are actions that show respect of the host family for the family dan people around them. The host family elevates the people around them by coming to their home to give news and invite them.

Behavior or trust is represented in the stages of Morge Siwe's pre-wedding ceremony named Sorah Gawe pada Proatin. This traditional ceremony is done by the host family come and entrust the traditional event to the proatin (head of the village). This represents the trust of the host family to proatin to proceed the wedding ceremony. Proatin will carry out this belief as best as possible by doing the wedding ceremony as well as the host family wish. Proatin has the responsibility to carry out the wedding ceremony as a mandate that has been given to him.

\section{Cultural Meaning of Morge Siwe Wedding Ceremony}

Noble values as a form of cultural meaning represented in Morge Siwe wedding ceremony are not arrogant, upholding the values of politeness, humble, and can always adapt to the social environment. These values are reflected in title-giving stage to the bride and groom. Kayu Agung people call it as Ngoni Cangkingan. Ngoni Cangkingan is a title-giving stage to someone who has released his single. The titles given are usually Wiralaga, Singa de Kane, Tande Imam, Kasihan Raja, Radi Akuan, and Prabu Anom. It is usually derived from the groom's offspring through the grandfather or great-grandfather lineage. In this procession, poetry about life as an advice for the bride to enter a new life, namely family life, will be read. This stage is usually held after Ijab Kabul is held.

The values of politeness, not being arrogant, and being humble are represented in the verses uttered by the chieftain at that time. Asking permission and expressing gratitude for being given the trust to carry out this stage is a representation of attitudes and behaviour that prioritize and uphold politeness. Asking permission and saying thank you has a positive effect: it makes other people happy. This behaviour shows that permission is a very important thing to do so that it will be well done. Kayu Agung people considers that asking for permission is a behavior that teaches good manners to behave politely to others. This is represented in the following verse.

Lamonlah sampan mencing karonah.

Lamonlah langgang ketanggapan

Hendaklah badang renggang manongah

Lamonlah badan ketangaan, you pun

(If it is true that I have been permitted, I will ask that you pleased me to perform.)

Humility makes people not arrogant. Even though their abilities are not possessed by others, the title-giver does not brag. He remains humble because he knows he has no position and there are actually people who are worthier than him, namely chieftain and the village head. An attitude of respecting each other by keep humble. Attitudes and behaviours like these have a very big contribution in reducing social conflict. This attitude is represented in the following verse quote.

These characters are represented in these following verse quote.

Gilo kiapo memanggang di abu.

Api ado baronyo ado 


\section{Gilo dia apo menyuruh aku}

Batin ado, pemangku ado di rumah ini. You pun

(Why ask me to be someone who has nothing, even though there are chieftain here, the Village Head is also there.)

One of the social things that can be used to live a good social life is the willingness to adapt to the new environment and culture. It is a form of respect to society and culture around it. This is represented in the following verse quote.
Mincang-mincang jangan kembung
Mincang kiranting janan patan
Mincang kedaun jangan layu, you pun
(Di mana bumi dipijak di situ langit dijunjung, we must be able to adapt to the society, and customary law in everywhere is like a proverb pandai-pandai menitih buih, selamat badan sampai tujuan.)

\section{Cultural Meaning of Morge Siwe Post-wedding}

The last procession in Morge Siwe's wedding ceremony is anan tuwoni. In the process, the noble values are represented to reach agreement, reciprocate, obey to parents, and keep get in touch. An attitude or behaviors of never forgetting one's kindness are deeply embedded in Kayu Agung people and they keep this culture or traditions they have. Ngulangkan Pungkal is one of traditions as a form of respecting for their ancestors who have inherited local culture. In this stage, the host family will go to relatives and neighbors to thank you for being helped to held the wedding. In addition, the host family also repaid their kindness by giving water to fill the water reservoir to be used for the needs in pungkal house.

Deliberation to reach agreement is represented in a procession of live permanently patterns after marriage. If the groom is the eldest child, in Morge Siwe's wedding tradition, the bride and groom stay in the house of the male parents. This is because the eldest son is pulau penyangge rompon or balancing child. The children of pulau penyangge rompon have an obligation to be responsible for his younger siblings if one day their parents die. On the other hand, if the bride is the eldest child and all her siblings are girl, the groom will be adopted as the eldest son, called as kakuk. Kakuk have responsibilities pulau penyangge rompon. Therefore, the bride and groom have to stay in the house of the woman's parents.

It is a thing that still can be negotiated. If the conditions do not allow the groom to stay in his house or in his parents-in-law's house, or even want to live in his own house for some reason, he can meet with the family and make a deal to reach an agreement. The deliberation will give a wise decision for everyone. Neither person is disadvantaged or benefited. It usually gives a goodness for everyone.

Nganan tuwuikon maju is a traditional wedding procession of the groom's family taking the bride home to her parents to stay overnight. This procession is used to give the bride an opportunity to be spoiled by her parents before being brought by her husband. The opportunity of the bride to give more attention to her parents before her attention is fully focused on her husband. Usually, the bride will get advice from her parents about marriage. It is about being a wife who respects and serves her husband with all her heart.

After one night the bride stay overnight there, the groom then caught up with his wife. The traditional procession of the groom comes to his parents-in-laws' house and caught up with his wife that accompanied by his parents and his family, called as anan tuwoi semehongot. Because of these traditional processions, a strong relationship will be established between the two families that are united through the marriage. Giving opportunity for wife to stay overnight at 
her parents' house and the husband coming with relatives to the parents-in-law's house with the aim of picking up the wife represents a respectful attitude towards the parents.

\section{Conclusion}

The traditions that arise, live, develop, and survive in a social community are assets that they should protect and preserve. This is because an oral tradition is full of noble values that can be applied in social and individual life. Morge Siwe traditional wedding ceremony which is owned by Kayu Agung people, South Sumatra is full of noble heritage values. Each stage of a traditional event contains cultural meanings that represent a very great culture. The culture traditions that uphold social values are trust, respect, unity and integrity, helping, politeness, deliberation for agreement, reciprocating, and keep getting in touch between each other. Besides that, the values of humans as individual beings also appear in these cultures, such as not being arrogant, being humble, always adapting to the society, obey and respecting their parents.

\section{References}

[1] Nurmalinda. 2016. Implementasi Nilai-Nilai Kearifan Lokal (Local Genius) dalam Tradisi Perayaan Anak Yatim pada Masyarakat Melayu Kuok Kabupaten Kampar Propinsi Riau. Prosiding Seminar Antar Bangsa : Seni Budaya dan Desain - STANSA. Halaman 236-245.

[2] Sibarani, Robert 2012. Kearifan Lokal: Hakikat, Peran dan Metode Tradisi Lisan. Jakarta: Asosiasi Tradisi Lisan.

[3] [3] Supriatin, Yeni Mulyani. 2012. "Tradisi Lisan dan identitas Bangsa: Studi Kasus Kampung Adat Sinarresmi, Sukabumi.” Patanjala Jurnal Penelitian Sejarah dan Budaya. Volume 4 Nomor 3. Halaman 407-418.

[4] Sedyawati, Edi. 1996. "Kedudukan Tradisi Lisan dalam Ilmu-Ilmu Sosial dan Ilmu-Ilmu Budaya." Warta ATL. Edisi II/Maret. Halaman 5-6.

[5] Setiadi, Elly. M. 2006. Ilmu Sosial dan Budaya Dasar. Jakarta: Kencana.

[6] Danandjaja, James. 1997. Folklor Indonesia: Ilmu Gosip, Dongeng, dan lain lain. Cetakan V. Jakarta: PT Pustaka Utama Grafiti.

[7] Pora, Syahyunan. 2016. "Identifikasi Nilai Kearifan Lokal dalam Tradisi Lisan Masyarakat Ternate. Jurnal Etnohistory. Volume III/1. Halaman 43-57.

[8] Undang-Undang Republik Indonesia Nomor 1 Tahun 1974 Tentang Perkawinan, https://m.hukumonline.com/pusatdata/detail/26834/undangundang-nomor-1-tahun-1974\#. Diunduh pada 5 Oktober 2020 pukul 07.32.

[9] Malefijt, Annemarie de Waal. 1986. Religion and Culture Al Introduction to Anthropology of Religion. N.Y.: The Macmillan Company.

[10] Suyitno. 1986. Sastra Tata Nilai, dan Eksegesis. Yogyakarta: PT Hanindita.

[11] Yohana, Nova dan Kurnia Husmiwati. 2015. "Kaidah Interaksi Komunikasi Tradisi Lisan Basiacuang dalam Adat Perkawinan Melayu Kampar Riau.” Jurnal Penelitian Komunikasi. Volume 18/1. Halaman 43-56.

[12] Eller, Jack David. 2007. Introducing Anthropology of Religion Culture to the Ultimate. Newyork and London: Routledge.

[13] Barthes, Roland. 2007. Petualangan Semiologi. Yogyakarta: Pustaka Pelajar. 